\title{
Relationships Between Black-Legged Kittiwake Nest-Site Characteristics and Susceptibility to Predation by Large Gulls
}

\author{
Author(s): Melanie Massaro, John W. Chardine, Ian L. Jones
}

Source: The Condor, 103(4):793-801. 2001.

Published By: Cooper Ornithological Society

DOI: http://dx.doi.org/10.1650/0010-5422(2001)103[0793:RBBLKN]2.0.CO;2

URL: http://www.bioone.org/doi/full/10.1650/0010-5422\%282001\%29103\%5B0793\%3ARBBLKN

$\% 5 \mathrm{D} 2.0 . \mathrm{CO} \% 3 \mathrm{~B} 2$

BioOne (www.bioone.org) is a nonprofit, online aggregation of core research in the biological, ecological, and environmental sciences. BioOne provides a sustainable online platform for over 170 journals and books published by nonprofit societies, associations, museums, institutions, and presses.

Your use of this PDF, the BioOne Web site, and all posted and associated content indicates your acceptance of BioOne's Terms of Use, available at www.bioone.org/page/terms_of_use.

Usage of BioOne content is strictly limited to personal, educational, and non-commercial use. Commercial inquiries or rights and permissions requests should be directed to the individual publisher as copyright holder. 


\title{
RELATIONSHIPS BETWEEN BLACK-LEGGED KITTIWAKE NEST- SITE CHARACTERISTICS AND SUSCEPTIBILITY TO PREDATION BY LARGE GULLS
}

\author{
Melanie Massaro ${ }^{1,3}$, John W. Chardine ${ }^{2}$ and Ian L. Jones ${ }^{1}$ \\ ${ }^{1}$ Atlantic Cooperative Wildlife Ecology Research Network, Department of Biology, \\ Memorial University of Newfoundland, St. John's, Newfoundland A1B 3X9, Canada \\ ${ }^{2}$ Canadian Wildlife Service, P.O. Box 6227, Sackville, New Brunswick E4L 1G6, Canada
}

\begin{abstract}
We quantified the relationship between Black-legged Kittiwake (Rissa tridactyla) nest-site characteristics and risk of predation by Great Black-backed (Larus marinus) and Herring (L. argentatus) Gulls at Gull Island, Newfoundland, Canada, during 1998 and 1999. We monitored kittiwake nesting cliffs to identify nest sites attacked by large gulls and compared characteristics of attacked and successful nests among four study plots. We also examined which nest sites were attacked by Herring or Great Black-backed Gulls during calm $\left(\leq 10 \mathrm{~km} \mathrm{hr}^{-1}\right)$ or windy conditions $\left(>10 \mathrm{~km} \mathrm{hr}^{-1}\right)$. We found that kittiwake nests on plots with fewer nests were more likely to be attacked by gulls and less likely to fledge young. Nest density and nest location relative to the cliffs' upper edges significantly affected the risk of gull predation. Breeding success was correlated with nest density and ledge width and differed significantly among plots. Regardless of wind conditions both gull species were more likely to attack nests located on upper sections of cliffs than nests on lower sections. However, during calm conditions, nest sites located on narrow ledges were less likely to be attacked by Great Black-backed Gulls. Our results demonstrate that for kittiwake colonies where predation is an important source of breeding failure, the size of subcolonies and nest density affect the survival of kittiwake offspring.
\end{abstract}

Key words: Black-legged Kittiwake, breeding habitat, coloniality, Larus, nest-site characteristics, predation risk, Rissa tridactyla.

Relación entre las Características de los Sitios de Nidificación de Rissa tridactyla y la Susceptibilidad a la Depredación por parte de Gaviotas

Resumen. Cuantificamos la relación entre las características de los sitios de nidificación de Rissa tridactyla y el riesgo de depredación por parte de Larus marinus y L. argentatus en la Isla Gull, Newfoundland, Canadá, durante 1998 y 1999. Con el objetivo de identificar los nidos atacados por gaviotas de gran tamaño, monitoreamos acantilados de nidificación de $R$. tridactyla en cuatro localidades de estudio y comparamos las características de los nidos atacados y exitosos. También examinamos qué nidos fueron atacados por L. marinus o por L. argentatus durante condiciones de viento calmo $\left(\leq 10 \mathrm{~km} \mathrm{hr}^{-1}\right)$ o ventosas $\left(>10 \mathrm{~km} \mathrm{hr}^{-1}\right)$. Encontramos que los nidos de $R$. tridactyla ubicados en localidades con menor número de nidos tuvieron mayor probabilidad de ser atacados y menor probabilidad de criar volantones. Tanto la densidad como la ubicación de los nidos en relación al vértice superior del acantilado afectaron significativamente el riesgo de depredación por gaviotas. El éxito de cría se diferenció significativamente entre localidades y se correlacionó con la densidad de nidos y con el ancho de la plataforma. Independientemente de la velocidad del viento, las dos especies de gaviotas atacaron con mayor probabilidad a los nidos ubicados en las secciones superiores del acantilado que en las secciones inferiores. Sin embargo, durante condiciones de viento calmo, los nidos localizados en plataformas angostas presentaron una menor probabilidad de ser atacados por L. marinus. Nuestros resultados demuestran que para colonias de $R$. tridactyla en las cuales la depredación de nidos es un factor importante en el fracaso reproductivo, el tamaño de las subcolonias y la densidad de nidos afecta la supervivencia de la progenie de $R$. tridactyla.

Manuscript received 28 July 2000; accepted 28 July 2001.

${ }^{3}$ Present address: Department of Zoology, University of Otago, P.O. Box 56, Dunedin, New Zealand. E-mail: masme209@student.otago.ac.nz 


\section{INTRODUCTION}

In birds, the selection of cliffs as breeding habitats likely evolved as a response to predation by terrestrial mammals (Cullen 1957, Tuck 1961, Birkhead et al. 1985). As several studies have shown, cliff-nesting does not necessarily protect birds from avian predation; in particular, some members of the families Laridae and Corvidae are successful in preying upon cliff-nesting bird species (Maccarone 1992, Gaston and Elliott 1996, Gilchrist and Gaston 1997).

Black-legged Kittiwakes (Rissa tridactyla) breed in colonies on steep cliffs. While many kittiwake colonies, mainly in the United Kingdom and Alaska, lose only few offspring to large gulls, ravens, or crows (Coulson 1963, Maunder and Threlfall 1972, Murphy et al. 1991), other colonies experience greater rates of avian predation (Barrett and Runde 1980, Maccarone 1992). On the southeastern coast of Newfoundland, Canada, reduced availability of fisheries waste and marine prey for Herring and Great Black-backed Gulls have caused gull predation on kittiwakes to increase markedly since the early 1990s (Regehr and Montevecchi 1997, Massaro et al. 2000). We hypothesized that under conditions of high predation pressure, colony size, nest density, and specific nest-site characteristics may play a role in reducing the risk of predation and thus enhance reproductive success of Black-legged Kittiwakes. As shown for other seabirds, breeding in large colonies with high nest densities offers advantages to individual birds due to increased vigilance, group defense, and predator swamping (Burger and Gochfeld 1994, Wittenberger and Hunt 1985, Gilchrist and Gaston 1997, Gilchrist et al. 1998). Cullen (1957) suggested that with the adoption of cliffnesting, kittiwakes lost or at least reduced their mobbing behavior as a predator defense tactic, as observed in many ground-nesting gulls (Shealer and Burger 1992, Yorio and Quintana 1997). However, kittiwakes may defend their offspring against predators if faced with a high risk of predation (Andersson 1976).

Although Regehr et al. (1998) investigated the relationship between nest-site characteristics and breeding performance of Black-legged Kittiwakes, their study used survival time of kittiwake chicks and eggs to infer which nest-site characteristics may reduce gull predation without directly observing gull predation attempts.
The aim of this study was to quantify the relationship between kittiwake nest-site characteristics and susceptibility to Herring and Great Black-backed Gull predation by observing which nest sites were and were not attacked by large gulls. We tested whether plot, nest density, nest location relative to the cliffs' upper edge, ledge width, roof, or number of walls affected which nest sites were attacked. We evaluated whether breeding success was influenced by the same nest-site characteristics that prevented gull attacks.

Wind conditions constrained the foraging ability of Glaucous Gulls (L. hyperboreus) preying upon Thick-billed Murre (Uria lomvia) eggs (Gilchrist and Gaston 1997, Gilchrist et al. 1998). To evaluate whether foraging decisions of Herring or Great Black-backed Gulls changed due to wind conditions we compared which kittiwake nests were attacked during calm or windy conditions.

\section{METHODS}

\section{STUDY LOCATION AND STUDY PLOTS}

This study was conducted from 24 May to 15 August 1998 and 16 May to 9 August 1999 on Gull Island $\left(47^{\circ} 16^{\prime} \mathrm{N}, 52^{\circ} 46^{\prime} \mathrm{W}\right)$, the most northerly of four islands within the Witless Bay Seabird Ecological Reserve off the southeastern coast of Newfoundland, Canada. Gull Island offers breeding habitat to about 5000 pairs of Black-legged Kittiwakes, 2800 pairs of Herring Gulls, and 115 pairs of Great Black-backed Gulls (G. J. Robertson et al., unpubl.).

We selected four west-facing kittiwake cliffs as study plots, which differed in size, height, and overall cliff structure. All plots were located at the southern end of the island, but were at least $200 \mathrm{~m}$ apart (Fig. 1). Three of the four plots (N4, $\mathrm{S} 5, \mathrm{~S} 1$ ) were within protected gulches (narrow inlets) that opened onto the sea at angles of 16$20^{\circ}$, and one (P2) was part of an open cliff face at the edge of the island. Cliff height varied from 6-20 m (Fig. 1). All nests were included in the study plots on each cliff, except at P2 where we drew an imaginary vertical line from a rock ledge where murres bred to define the south end of plot P2.

\section{DATA COLLECTION}

In both years all nests at the four study plots were individually numbered, photographed and mapped. At all four kittiwake plots, 2-4-hr 


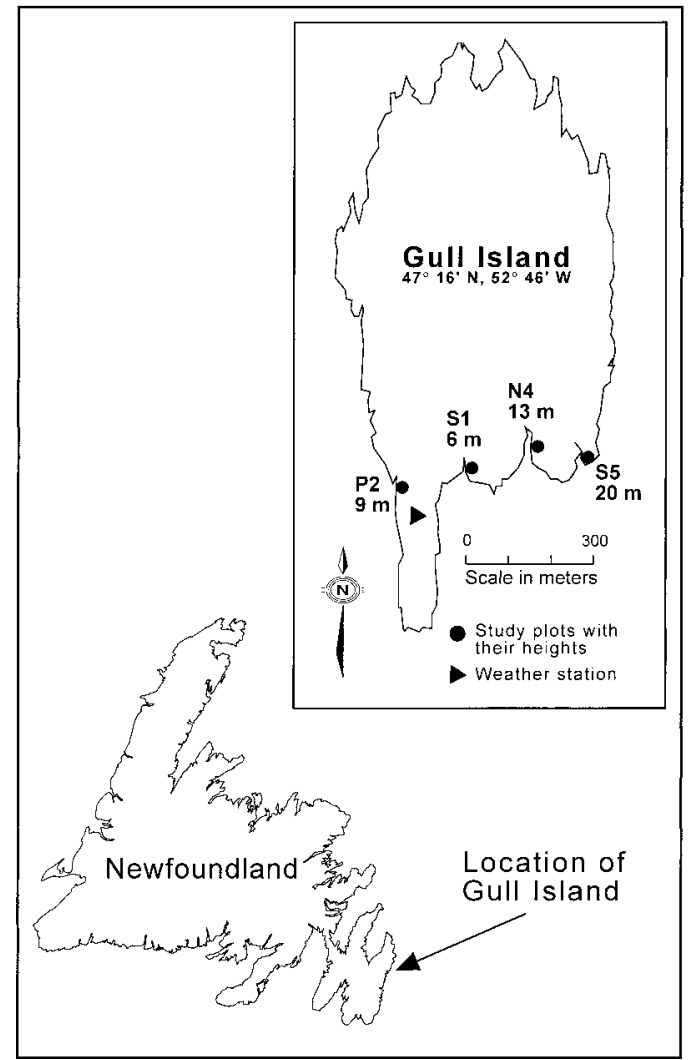

FIGURE 1. Gull Island, Witless Bay Ecological Reserve, located off the southeastern coast of Newfoundland, Canada. The position of the weather station and the four kittiwake study plots (S1, P2, N4, and S5) studied during 1998-1999 are indicated. The heights of the kittiwake nesting cliffs are reported (measured from sea level to the cliffs' upper edge).

watches were usually conducted twice per week throughout the breeding season. Total observation times were $286 \mathrm{hr}$ in 1998 , and $426 \mathrm{hr}$ in 1999, of which $192 \mathrm{hr}$ were at N4, $159 \mathrm{hr}$ at S5, $196 \mathrm{hr}$ at P2, and $165 \mathrm{hr}$ at S1. To ensure normal, undisturbed predatory behavior of gulls all observations were made from blinds. Observers in blinds faced the study plots from distances of 10-30 m. We entered blinds approximately 5 min before a watch started to allow gulls to settle down after our arrival. There was no evidence that predation attempts were more frequent at the beginning of a watch due to the observers' approach to the colony. A predation attempt was defined as an occasion when a large gull closely approached one or more kittiwake nests and elicited such responses as turning to- ward the gull and calling loudly, jabbing with the bill, pecking, biting, or diving at the gull. For each Herring Gull or Great Black-backed Gull predation attempt, whether successful or unsuccessful, we recorded which nest was attacked. If more than one kittiwake nest was attacked during a predation attempt we chose one of the nests randomly to ensure independence, and included it in the analyses. Nests that were attacked by Herring or Great Black-backed Gulls at least once in 1998 or 1999 were classified as "attacked" nests.

Contents of all numbered kittiwake nests at the four plots were monitored approximately twice per week, except at plot P2 where no breeding data were collected in 1999. Kittiwake chicks that survived 35 days or more were considered to have fledged. Occasionally kittiwake chicks between the ages of 30 and 35 days disappeared ( $n=76$ chicks); those chicks (9\% of all fledged chicks) were assumed to have fledged and were included in the analysis. All nests where one or more chicks fledged in 1998 or 1999 were considered "successful." Because not all gull predation attempts were successful, some nests were successful in raising chicks despite having been attacked by gulls.

To minimize disturbance to breeding birds, nest-site characteristics were quantified during late chick rearing in both years by observation from a distance of 10-30 m with binoculars and a $30 \times 75$ spotting scope. For each kittiwake nest site we recorded five characteristics: (1) nest density (low, medium, or high), (2) horizontal cliff section (upper or lower), (3) ledge width (broad or narrow), (4) roof (roof or no roof), and (5) number of vertical walls $(<2$ or $\geq 2$ ). For the variable "nest density" we counted for each nest site the number of nests within a radius of three kittiwake body lengths (approximately a radius of $0.8 \mathrm{~m} ; 1.8 \mathrm{~m}^{2}$ ) including the focal nest. Sites with 1-2 nests within $1.8 \mathrm{~m}^{2}$ were classified as low density, 3 nests within 1.8 $\mathrm{m}^{2}$ were classified as medium density, and $\geq 4$ nests within $1.8 \mathrm{~m}^{2}$ were classified as high density areas. Nests within $3 \mathrm{~m}$ of the cliffs' upper edge were classified as in the upper section of the cliff. We used a Bushnell laser rangefinder, a clinometer, and trigonometry to measure the distance to the nearest meter between the nest site and the cliff edge. We classified the different categories of ledge width, roof, and walls following Gaston and Nettleship (1981 Fig. 71). A 
nest was considered to be on a narrow ledge if the nest material hung over the seaward edge. A nest site had a roof if the nest cup was overhung by rock within twice the height of an adult kittiwake. Walls had to be at least the height of a sitting adult kittiwake and at least as wide as a nest cup to be counted.

During both seasons, wind speed and direction were measured hourly by a weather station (Weather Wizzard III, Davis Instruments Corp., Hayward, California) located on an exposed hill at the southwestern end of Gull Island (Fig. 1). The measuring device was fixed to a tree trunk approximately $1.8 \mathrm{~m}$ above ground. Due to a programming mistake the weather station did not collect any data for May and June 1999. To compensate, we measured wind conditions with a handheld anemometer during most predation watches at the kittiwake study plots. For 16 occasions the wind conditions during gull predation attempts were unknown and we used wind data collected by Environment Canada at the St. John's airport, located approximately $35 \mathrm{~km}$ to the north of the study area. For each gull predation attempt we classified the wind condition either as calm $\left(\leq 10 \mathrm{~km} \mathrm{hr}^{-1}\right)$ or as windy $(>10$ $\mathrm{km} \mathrm{hr}^{-1}$ ), but only if wind directions were within the opening angles of the cliffs. For P2, only westerly $\left(180-360^{\circ}\right)$ winds over $10 \mathrm{~km} \mathrm{hr}^{-1}$ were considered windy. For the other three plots only south-south-easterly to south-south-westerly winds $\left(157.5-202.5^{\circ}\right)$ over $10 \mathrm{~km} \mathrm{hr}^{-1}$ were considered windy.

\section{STATISTICAL ANALYSES}

Only kittiwake nests that were active ( $\geq 1$ egg was laid) in 1998 or 1999 were included in analyses. Regardless if nest sites were occupied by kittiwakes or attacked by gulls in one or both years, each nest was only included as one data point to avoid pseudoreplication. For all statistical analyses we used SPSS version 10 (SPSS Inc. 1999) or DataDesk version 5 (Data Description Inc. 1995). The tolerance for type I error was set at 0.05 .

To test whether the proportion of attacked nests differed among plots we used a chi-square test. To be able to include nest density as an independent variable in the attack analysis and breeding success analysis we chose randomly 300 nests (out of 659) and used these as our sample. We used logistic regressions with binary response variables (attack analysis: attacked or not attacked; breeding success analysis: successful or not successful in raising a chick) to test whether our six categorical independent variables (plot, density, cliff section, ledge width, roof, and number of walls) influenced the probability of large gull attacks and breeding success.

To evaluate whether Herring or Great Blackbacked Gulls attacked different nest sites in variable wind conditions we randomly chose 300 nests out of 617 active nests from three study plots (N4, S5, and P2). Plot S1 was excluded from these analyses because only Herring Gulls foraged at this plot, and only during calm conditions. We had four response variables: attacked or not attacked (1) by Herring Gulls during calm conditions, (2) by Great Black-backed Gulls during calm conditions, (3) by Herring Gulls during windy conditions and (4) by Great Blackbacked Gulls during windy conditions. We did four logistic regressions, one for each response variable, testing for effects of the six independent variables.

\section{RESULTS \\ PLOT VARIATION}

The number of nests and the percentage of nests with each nest-site characteristic are reported in Table 1 for all study plots. The proportion of nests attacked differed significantly among plots $\left(\chi_{3}^{2}=53.1, P<0.001\right)$. Plot S1 had the highest percentage of attacked nest sites, followed by P2, N4, and S5 (Fig. 2). The percentage of successful nests in 1998 or 1999 varied significantly among plots $\left.\chi_{3}^{2}=40.6, P<0.001\right)$. Plot S1, which had the highest proportion of attacked nests, also had the lowest percentage of sites that raised chicks, followed by plot $\mathrm{P} 2$ and plots $\mathrm{S} 5$ and N4 (Fig. 2).

\section{NEST-SITE CHARACTERISTICS}

In the analysis of 300 randomly chosen nest sites, plot, nest density, and cliff section had significant effects on which nest sites were attacked by gulls (Table 2). Comparisons of attack rates among plots were comparable to results from whole-plot analysis (Fig. 2): attack rates were greater for smaller than larger plots. Nest sites in high and medium density areas were more likely to be attacked (high: 30\%, 14 of 46 nests; medium: $33 \%$, 37 of 114 nests) than nests in low density areas (17\%, 24 of 140 nests). Nests at upper sections were more likely to be attacked 
TABLE 1. The number $(\%)$ of active Black-legged Kittiwake nests ( $\geq 1$ egg was laid) falling within each category of nest-site characteristic, for each of the four study plots on Gull Island, Newfoundland, in 1998 and 1999.

\begin{tabular}{|c|c|c|c|c|}
\hline Nest-site characteristics & $\begin{array}{l}\text { Plot S1 } \\
n=42\end{array}$ & $\begin{array}{l}\text { Plot P2 } \\
n=81\end{array}$ & $\begin{array}{c}\text { Plot N4 } \\
n=268\end{array}$ & $\begin{array}{c}\text { Plot S5 } \\
n=268\end{array}$ \\
\hline \multicolumn{5}{|l|}{ Density } \\
\hline low & $18(43)$ & $31(38)$ & $128(48)$ & $115(43)$ \\
\hline medium & $21(50)$ & $39(48)$ & $111(41)$ & $80(30)$ \\
\hline high & $3(7)$ & $11(14)$ & $29(11)$ & $73(27)$ \\
\hline \multicolumn{5}{|l|}{ Cliff section } \\
\hline upper section & $35(83)$ & $47(58)$ & $70(26)$ & $64(24)$ \\
\hline lower section & 7 (17) & $34(42)$ & $198(74)$ & $204(76)$ \\
\hline \multicolumn{5}{|l|}{ Ledge width } \\
\hline broad & $18(43)$ & $24(30)$ & $100(37)$ & $124(46)$ \\
\hline narrow & $24(57)$ & $57(70)$ & $168(63)$ & $144(54)$ \\
\hline \multicolumn{5}{|l|}{ Roof } \\
\hline roof & $15(36)$ & $53(65)$ & $180(67)$ & $115(43)$ \\
\hline no roof & $27(64)$ & $28(35)$ & $88(33)$ & $153(57)$ \\
\hline \multicolumn{5}{|l|}{ No. walls } \\
\hline$<2$ walls & $29(69)$ & $72(89)$ & $219(82)$ & $230(86)$ \\
\hline$\geq 2$ walls & $13(31)$ & $9(11)$ & 49 (18) & $38(14)$ \\
\hline
\end{tabular}

(45\%, 44 of 97 nests) than sites at lower sections of the cliff (15\%, 31 of 203 nests). Ledge width, roof presence/absence, and number of walls did not affect attack rates.

Plot, nest density, and ledge width significantly affected breeding success of kittiwakes for 300 randomly chosen nests (Table 3). Comparisons of breeding success among plots were comparable to results from whole-plot analysis (Fig. 2): nests on smaller plots were less successful than those on larger plots. Nest sites in

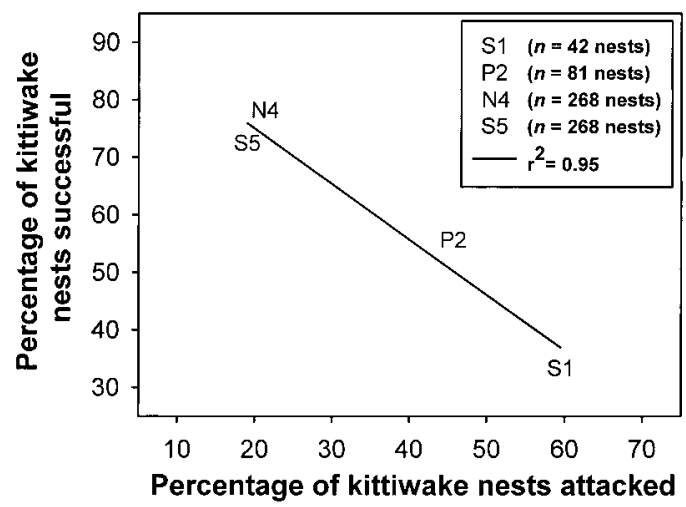

FIGURE 2. Relationship between the percentage of Black-legged Kittiwake nests that were attacked by Herring and Great Black-backed Gulls and the percentage of kittiwake nests that raised at least one chick at each plot on Gull Island, Newfoundland, 19981999. The number of active nests ( $\geq 1$ egg was laid in either 1998 or 1999) is indicated. high density areas were more successful in raising chicks (74\%, 34 of 46 nests) than sites in medium density (68\%, 78 of 114 nests) and low density areas (64\%, 90 of 140 nests). Nests on narrow ledges were more successful $(73 \%, 134$ of 184) than sites on broad ledges $(59 \%, 68$ of 116). Cliff section, roof presence/absence, and number of walls did not influence breeding success.

\section{GULL FORAGING BEHAVIOR AND WIND CONDITIONS}

During calm conditions, nest sites on the upper sections of cliffs were more likely to be attacked by Herring and Great Black-backed Gulls than nests on lower sections (Fig. 3). Further, nest sites on broad ledges were more likely to be attacked by Great Black-backed Gulls during calm

TABLE 2. Logistic regression model of Black-legged Kittiwake nest-site characteristics' effects on the risk of predation attacks by Herring and Great Blackbacked Gulls on Gull Island, Newfoundland, in 1998 and 1999 ( $n=300$ randomly chosen sites).

\begin{tabular}{lcrl}
\hline \hline \multicolumn{1}{c}{ Source } & df & Wald & $P$ \\
\hline Plot & 3 & 22.0 & $<0.001$ \\
Density & 2 & 6.1 & $<0.05$ \\
Cliff section & 1 & 15.2 & $<0.001$ \\
Ledge width & 1 & 0.2 & 0.6 \\
Roof & 1 & 0.4 & 0.5 \\
No. walls & 1 & 1.9 & 0.2 \\
\hline
\end{tabular}


TABLE 3. Logistic regression model of Black-legged Kittiwake nest-site characteristics' effects on the breeding success of kittiwakes on Gull Island, Newfoundland, in 1998 and 1999 ( $n=300$ randomly chosen sites).

\begin{tabular}{lccc}
\hline \hline \multicolumn{1}{c}{ Source } & df & Wald & $P$ \\
\hline Plot & 3 & 21.4 & $<0.001$ \\
Density & 2 & 6.4 & $<0.05$ \\
Cliff section & 1 & 0.04 & 0.8 \\
Ledge width & 1 & 10.5 & $<0.01$ \\
Roof & 1 & 0.2 & 0.7 \\
No. walls & 1 & 0.9 & 0.3 \\
\hline
\end{tabular}

We found a negative relationship between the proportions of kittiwake nests attacked by gulls and kittiwake breeding success in relation to plot size. The frequency of gull predation attempts per plot was lowest for S1 (Massaro et al. 2000),

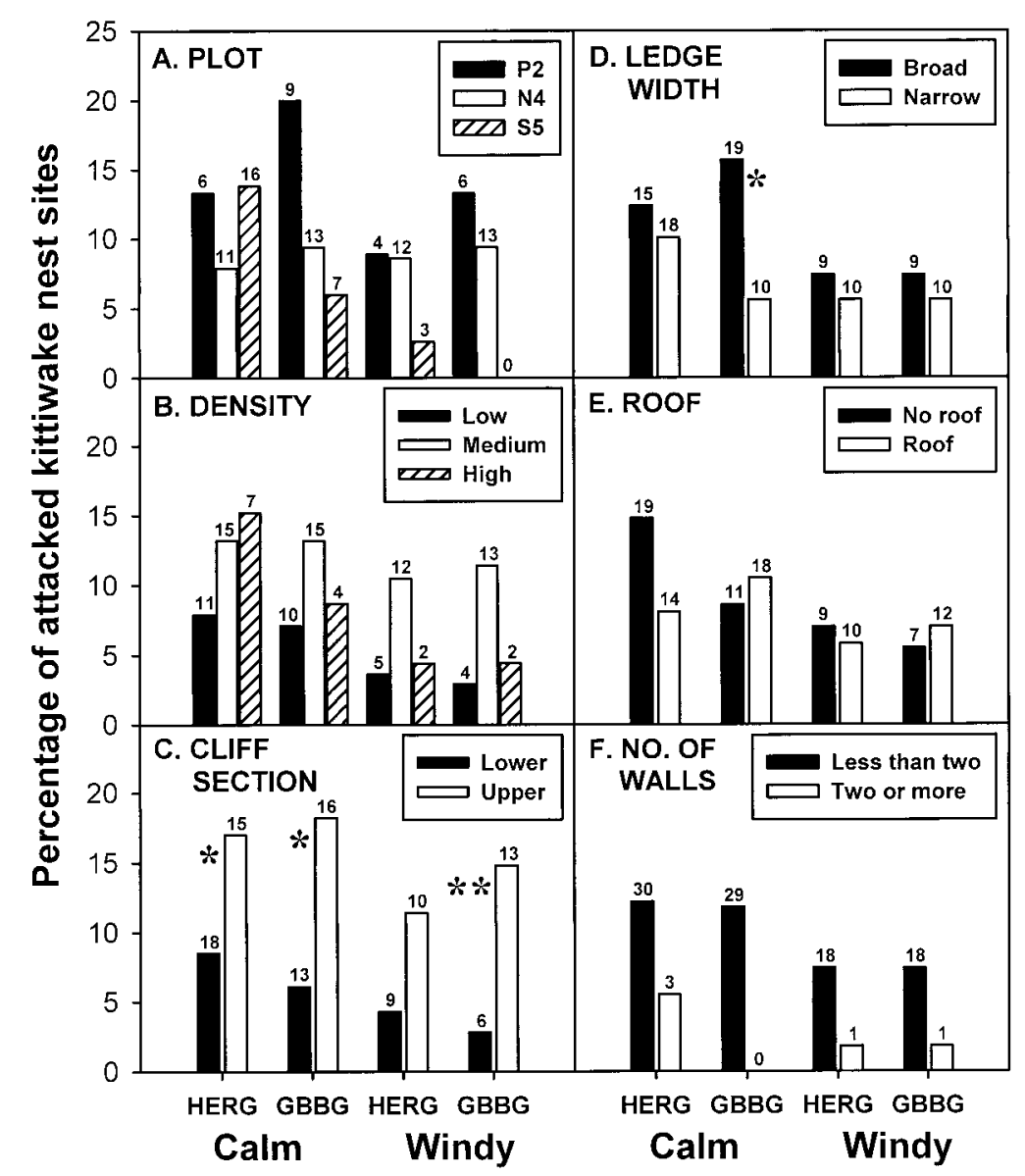

FIGURE 3. Percentage of 300 randomly chosen kittiwake nests that were attacked by Herring Gulls (HERG) or Great Black-backed Gulls (GBBG) during calm or windy conditions. Graphs indicate the effects of (A) plot, (B) density, (C) cliff section, (D) ledge width, (E) roof, and (F) the number of walls. Sample sizes of attacked nests are recorded above each bar. Statistical significance is indicated $(* P<0.05, * * P<0.01)$. 
but individual kittiwake nests on this smallest plot experienced the highest predation risk and the lowest breeding success of all plots. Predators are attracted to seabird colonies because a large concentration of food is available (Wittenberger and Hunt 1985). On Gull Island, the smallest plot, S1, was occupied as a feeding territory by only one Herring Gull pair, while the largest plot, S5, was occupied by one Great Black-backed Gull pair and one Herring Gull pair (Massaro et al. 2000). It appears that larger kittiwake subcolonies attracted more and larger predators, increasing the frequency of predation attempts per plot (Massaro et al. 2000); however, the predation pressure for an individual kittiwake nest decreased as the size of the subcolony increased, resulting in a dilution of predation risk in larger plots.

Poor reproductive success by individuals in small nesting aggregations could have long-term effects on recruitment. Kittiwakes choose their nesting location based partly on their own breeding success and that of conspecific nesters during the previous breeding season (Danchin and Monnat 1992, Cadiou et al. 1994, Danchin et al. 1998). Low average breeding success at small subcolonies, such as $\mathrm{S} 1$, might cause recruiting kittiwakes to choose larger cliffs (Danchin et al. 1998).

\section{NESTING DENSITY}

In this study, the risk of attack was approximately twice as high for nest sites in high and medium density areas than for nests in low density areas. Despite this, kittiwakes nesting at high density were more successful in raising chicks than kittiwakes that nested in medium and low density areas. In bird species that mob predators, nesting in dense colonies is advantageous (Wittenberger and Hunt 1985). If the risk of predation is high, cliff-nesting Black-legged Kittiwakes defend their nests by vigorously mobbing avian predators (Andersson 1976, Montevecchi 1979, Maccarone 1992). During this study we frequently observed that kittiwake eggs and chicks were not only defended by their own parents, but also by mobbing neighbors that may have included prospectors and failed nesters. Kittiwakes that were more likely to defend and respond to an approaching gull were more often "attacked" by our definition but at the same time these kittiwakes were less likely to lose their offspring to a gull.

\section{CLIFF SECTION AND LEDGE WIDTH}

Nest sites at the upper sections of cliffs were more likely to be attacked than nests at lower sections. Similarly, Common Ravens (Corvus corax) on Baccalieu Island, Newfoundland, hunted along the upper third of a kittiwake nesting cliff on $49 \%$ of all patrols, $33 \%$ along the middle and $18 \%$ along the lower third of the cliff (Maccarone 1992). At a Thick-billed Murre colony, Gaston and Elliot (1996) found that 68\% of all predation attempts by ravens occurred in the upper $30 \%$ of the cliff. Peripheral sites were more likely to be attacked than central sites within the top 30\% of the cliff (Gaston and Elliot 1996).

While gull attacks were directed more often at nests located on upper sections of cliffs, we did not find any breeding success differences among upper and lower sections. However, ledge width influenced the breeding success of nests, whereby sites on narrow ledges were more successful. That nest-site characteristics influenced the risk of attack but not kittiwake breeding success may be explained by our sampling methods or treatment of data. The numbers of attacked kittiwake nests reported were only those from directly observed gull attacks occurring during limited observation sessions; hence the actual numbers of attacked kittiwake nests could be much higher. In contrast, productivity data were cumulative because events that occurred outside of the observation sessions were still detected during subsequent plot visits. Additionally, a nest was considered attacked or successful if either event occurred in either of the two years of the study. This raises the possibility that the treatment of the data added some noise to the relationship between attack rates and breeding success. However, the discrepancy between risk of attack and kittiwake breeding success may simply reflect that besides gull predation a wide variety of factors, such as quality and age of the pair or parasite abundance, also influence breeding success of kittiwakes (Coulson 1968, Coulson and Thomas 1984, Boulinier et al. 1997).

\section{GULL FORAGING DECISIONS}

Foraging decisions are influenced by the tradeoff between possible energy gain and the risk of injury (Stein 1977, Gilchrist et al. 1998). Thus opportunistic foragers, such as Herring and Great Black-backed Gulls, should confront these 
decisions frequently, because they are capable of switching to different prey (Pierotti and Annett 1987). Conditions that constrain the foraging ability of predators are highly dynamic due to changes in prey availability, competition among predator species, and environmental conditions (Verbeek 1977, Baird 1990, Anderson and Hodum 1993). Prey availability is likely to change for predatory gulls throughout the season due to previous depredations. Toward the end of the season gulls may be forced to forage on nests with less preferred characteristics after they have depleted nests that were easily reached and preyed upon. Due to a relatively small number of attacks that were observed to be successful (44 out of 318 attacks on nests), we did not test for this possibility.

Several studies have shown that avian predators respond to differential wind conditions by changing their foraging tactics (Spear and Anderson 1989, Young 1994, Gilchrist and Gaston 1997). Although both Herring Gulls (1080 \pm $137 \mathrm{~g}, n=106)$ and Great Black-backed Gulls $(1760 \pm 226 \mathrm{~g}, n=22$; G. J. Robertson, unpubl.) have similar values for wing loading (Pennycuick 1987, Spear and Ainley 1997), their foraging tactics differ due to their size. Regardless of wind conditions, Herring and Great Black-backed Gulls attacked a greater percentage of nest sites located at the upper sections of cliffs than at lower sections. Herring Gulls started most of their foraging attacks on kittiwakes from the upper edge of the cliff. From that position they either walked into the kittiwake colony or jumped into the air and flew in a small semicircle before attacking a site. Usually Herring Gulls obtained kittiwake eggs or chicks while supporting their own weight by rapid wing beating and lowering their feet onto the kittiwake ledge. Sometimes Herring Gulls removed adult kittiwakes from the nest before taking nest contents. During calm wind conditions Great Black-backed Gulls seldom attacked nests on narrow ledges. In contrast to Herring Gulls, Great Black-backed Gulls started most of their attacks by flying circles along the kittiwake nesting cliff. Usually they lowered their flight speed and then tried to land on a kittiwake ledge. Once landed, Great Black-backed Gulls walked among the kittiwake nests, obtaining eggs or chicks from all nests they could reach on the ledge.

Windy conditions likely increased the aerial maneuverability of both gull species. With increased wind speed, Herring Gulls appeared unconstrained by any nest-site characteristics. They foraged on the wing, almost hovering over a kittiwake cliff, and lunged suddenly at nests to obtain an egg or chick without landing. During calm conditions, the foraging of Great Blackbacked Gulls was constrained by ledge width (whereby nests on broad ledges were more likely to be attacked), whereas increased wind speed enabled them to attack nests on both narrow and broad ledges.

On Gull Island, gulls took approximately $43 \%$ and 30\% of all kittiwake offspring in 1998 and 1999, respectively (Massaro et al. 2000). We have shown that when predation on Black-legged Kittiwakes is as high as it was on Gull Island in 1998 and 1999, the size of subcolonies and nest density become crucial breeding habitat characteristics for the survival of kittiwake offspring. Further investigation on how habitat selection of cliff-nesting birds may constrain the foraging ability of avian predators should focus on two main issues: (1) wind conditions at different elevations of the cliff, and (2) foraging behavior and abilities of predators.

\section{ACKNOWLEDGMENTS}

We thank Keith Elms, Grant Gilchrist, Mark Hipfner, Bob Milko, Ted Miller, Greg Robertson, and Anne Storey for helping develop ideas and looking at earlier manuscripts. Sarah Boyne, Dave Fifield, and Dedreic Grecian helped in the field and we thank them for their great assistance. We are grateful for logistic help and constant support of the O'Briens Whale and Bird Tours in Bay Bulls. During this study MM received a scholarship from Memorial University of Newfoundland. We thank the Canadian Wildlife Service and the Atlantic Cooperative Wildlife Ecology Research Network for financial and logistic support. Thanks to Environment Canada, which provided weather data for 1999 and to the Department of Tourism, Culture and Recreation of Newfoundland and Labrador, which gave us permission to work on Gull Island. Further, we would like to thank Dean Kildaw, as a reviewer, for the helpful comments he made on a previous draft.

\section{LITERATURE CITED}

Anderson, D. J., AND P. J. Hodum. 1993. Predator behavior favors clumped nesting in an oceanic seabird. Ecology 74:2462-2464.

Andersson, M. 1976. Population ecology of the Longtailed Skua (Stercorarius longicaudus Vieill). Journal of Animal Ecology 45:537-559.

BAIRD, P. H. 1990. Influence of abiotic factors and prey distribution on diet and reproductive success of three seabird species in Alaska. Ornis Scandinavica 21:224-235. 
Barrett, R. T., And O. J. Runde. 1980. Growth and survival of nestling Kittiwakes Rissa tridactyla in Norway. Ornis Scandinavica 11:228-235.

Birkhead, T. R., E. Greene, J. D. Biggins, and D. N. NETTLESHIP. 1985. Breeding site characteristics and breeding success in Thick-billed Murres. Canadian Journal of Zoology 63:1880-1884.

Boulinier, T., O. Sorci, J.-Y. Monnat, And É. DanCHIN. 1997. Parent-offspring regression suggests heritable susceptibility to ectoparasites in a natural population of Kittiwake Rissa tridactyla. Journal of Evolutionary Biology 10:77-85.

Burger, J., AND M. GochFeld. 1994. Predation and effects of humans on island nesting seabirds. BirdLife Conservation Series 1:39-67.

Cadiou, B., J.-Y. Monnat, and É. Danchin. 1994. Prospecting in the Kittiwake, Rissa tridactyla: different behavioral patterns and the role of squatting in recruitment. Animal Behaviour 47:847-856.

Coulson, J. C. 1963. The status of the Kittiwake in the British Isles. Bird Study 10:147-167.

Coulson, J. C. 1968. Differences of the quality of birds nesting in the centre and on the edges of a colony. Nature 217:478-479.

Coulson, J. C., And C. Thomas. 1984. Differences in the breeding performance of individual kittiwake gulls Rissa tridactyla, p. 489-503. In R. M. Sibly and R. H. Smith [EDS.], Behavioural ecologyecological consequences of adaptive behaviour. Blackwell Scientific Publications, Oxford, UK.

Cullen, E. 1957. Adaptations in the Kittiwake to cliff nesting. Ibis 99:275-302.

Danchin, É., T. Boulinier, And M. Massot. 1998. Conspecific reproductive success and breeding habitat selection: implications for the study of coloniality. Ecology 79:2415-2428.

Danchin, É., AND J.-Y. Monnat. 1992. Population dynamics modelling of two neighbouring Kittiwake Rissa tridactyla colonies. Ardea 80:171-180.

DAtA Description Inc. 1995. Data Desk user's guide. Version 5.0. Data Description, Inc., Ithaca, NY.

Gaston, A. J., And R. D. Elliot. 1996. Predation by Ravens Corvus corax on Brünnich's Guillemot Uria lomvia eggs and chicks and its possible impact on breeding site selection. Ibis 138:742-748.

Gaston, A. J., AnD D. N. NetTleship. 1981. The Thick-billed Murres of Prince Leopold Island. Canadian Wildlife Service Monograph Series No. 6.

Gilchrist, H. G., AND A. J. GAStON. 1997. Effects of murre nest site characteristics and wind conditions on predation by Glaucous Gulls. Canadian Journal of Zoology 75:518-524.

Gilchrist, H. G., A. J. Gaston, and J. N. M. Smith. 1998. Wind and prey nest sites as foraging constraints on an avian predator, the Glaucous Gull. Ecology 79:2403-2414.

Maccarone, A. D. 1992. Predation by Common Ravens on cliff-nesting Black-legged Kittiwakes on Baccalieu Island, Newfoundland. Colonial Waterbirds 15:253-256.

Massaro, M., J. W. Chardine, I. L. Jones, and G. J. Robertson. 2000. Delayed capelin (Mallotus villosus) availability influences large gull predatory behaviour on Black-legged Kittiwakes (Rissa tri- dactyla), causing a reduction in kittiwake breeding success. Canadian Journal of Zoology 78:15881596.

Maunder, J. E., And W. Threlfall. 1972. The breeding biology of the Black-legged Kittiwake in Newfoundland. Auk 89:789-816.

MonTEVECCHI, W. A. 1979. Predator-prey relationships between ravens and kittiwakes. Zeitschrift für Tierpsychologie 49:136-141.

Murphy, E. C., A. M. Springer, And D. G. Roseneau. 1991. High annual variability in reproductive success of kittiwakes (Rissa tridactyla L.) at a colony in western Alaska. Journal of Animal Ecology 60: 515-534.

PenNyCUICK, C. J. 1987. Flight of auks (Alcidae) and other northern seabirds compared to southern Procellariiformes: ornithodolite observations. Journal of Experimental Biology 128:335-348.

Pierotti, R., And C. AnNetT. 1987. Reproductive consequences of dietary specialization and switching in an ecological generalist, p. 417-442. In A. C. Kamil, J. R. Krebs, and H. R. Pulliam [EDS.], Foraging behavior. Plenum Press, New York.

RegeHr, H. M., AND W. A. MonteVECCHI. 1997. Interactive effects of food shortage and predation on breeding failure of Black-legged Kittiwakes: indirect effects of fisheries activities and implications for indicator species. Marine Ecology Progress Series 155:249-260.

Regehr, H. M., M. S. Rodway, and W. A. MonteVECCHI. 1998. Antipredator benefits of nest-site selection in Black-legged Kittiwakes. Canadian Journal of Zoology 76:910-915.

Shealer, D. A., AND J. Burger. 1992. Differential responses of tropical Roseate Terns to aerial intruders throughout the nesting cycle. Condor 94:712719.

SPEAR, L. B., AND D. G. AINLEy. 1997. Flight behaviour of seabirds in relation to wind direction and wing morphology. Ibis 139:221-233.

SPEAR, L. B., AND D. W. ANDERSON. 1989. Nest-site selection by Yellow-footed Gulls. Condor 91:9199.

SPSS INC. 1999. SPSS Base 10.0. Applications Guide. SPSS Inc., Chicago.

STEIN, R. A. 1977. Selective predation, optimal foraging, and the predator-prey interaction between fish and crayfish. Ecology 58:1237-1253.

Tuck, L. M. 1961. The murres. Canadian Wildlife Service Monograph Series No. 1.

VerbeeK, N. A. M. 1977. Interactions between Herring and Lesser Black-backed Gulls feeding on refuse. Auk 94:726-735.

Wittenberger, J. F., And G. L. Hunt JR. 1985. The adaptive significance of coloniality in birds, p. 178. In D. S. Farner, J. R. King, and K. C. Parkes [EDS.], Avian biology. Vol. VIII. Academic Press, Orlando, FL.

Yorio, P., AND F. Quintana. 1997. Predation by Kelp Gulls Larus dominicanus at a mixed-species colony of Royal Terns Sterna maxima and Cayenne Terns Sterna eurygnatha in Patagonia. Ibis 139: 536-541.

YounG, E. 1994. Skua and penguin: predator and prey. Cambridge University Press, Cambridge, UK. 